\title{
ARE THERE COMMON ACADEMIC LIBRARY CUSTOMER VALUES?
}

\author{
Susan McKnight
}

\begin{abstract}
:
Objectives: This paper provides answers to the following questions: Is there a correlation between what library customers value and the questions asked in benchmarking satisfaction surveys? Is there a core set of academic library customer values? Are there differences between what academic library customers value in Australia when compared to their counterparts in England? Do library customer values change over time?

Methods: The results of two similar university libraries' Customer Value Discovery research are compared to each other, and also to the question set in the LibQUAL+ ${ }^{\mathrm{TM}}$ survey. As the Customer Value Discovery research was undertaken six years apart, the results are compared to see if there has been change over time.
\end{abstract}

Results: Academic library customers identified a core set of values, and these values mapped reasonably well to the LibQUAL+ ${ }^{\mathrm{TM}}$ instrument. However, there were unique value factors identified by the various customer segments that did not map. Some questions in LibQUAL+ ${ }^{\mathrm{TM}}$ were more detailed in their exploration of library staff attributes than customers identified in their value proposition. Customers identify their values without reference to library jargon.

Conclusions: Customer Value Discovery and LibQUAL+ ${ }^{\mathrm{TM}}$ are both valuable management tools that identify services and resources of importance to library customers.

\section{Research Paper}

Keywords: library customer values; Customer Value Discovery; LibQUAL+ ${ }^{\mathrm{TM}}$; customer satisfaction, academic libraries 


\section{INTRODUCTION AND STUDY PROBLEM}

The effective and efficient management of a library service requires maximising return on investment, not necessarily in a commercial sense, but by being certain that budget allocations and staff deployment are targeted to areas that will deliver value to library customers. Therefore, it is incumbent to know what services customers value to ensure that all decision making is based on data and not assumptions. But do we really know what library customers value?

Library user satisfaction surveys are used internationally to gauge the performance of a library. Tools such as LibQUAL+ ${ }^{\mathrm{TM}}$ Service Quality Survey and the Rodski Student Satisfaction Survey are used in Australia to measure student satisfaction with university library services, with the former in wide use in the higher education sector in the United Kingdom. These survey instruments use a suite of common questions that enable benchmarking of library services within the sector to ascertain how well one is performing against others. While this can be very useful, the question remains whether a service is delivering value to its customer base.

There is very little in the library-related professional literature about values per se, although Warnaby and Finney (2005) write about 'creating customer value' at the British Library. Is there a correlation of what library customers value and the questions that are asked in benchmarking satisfaction surveys? Is there a core set of academic library customer values? Can managers rely on the key areas identified in long standing and internationally used benchmarking instruments to guide decision-making and planning? Are there differences between what academic library customers value in Australia when compared to their counterparts in England?

This paper answers these questions by exploring the similarities and differences between two sets of library customer values: one for a university library service in Australia (Deakin University) and the other in England (Nottingham Trent University). Hofstede (1983) groups Australia and Great Britain together with Canada, New Zealand, USA and Ireland. Hofstede's research indicates that Australia and Great Britain have almost identical cultural values. This research will identify whether there are significant differences based on customer values in the two countries.

The Customer Value Discovery research data used to undertake these comparisons was gathered using the same methodology but the research was undertaken some years apart (1999 in Australia and 2005 in England). The impact of the passage of six years will also be examined in light of the fast pace of change occurring in the library and information sector. 
Below are the Hierarchies of Values for both university library services. The highest priority value is shown as $100 \%$ and the other value factors are weighted in accordance with importance when compared to the highest value. 
Comparison of University Library Value Factors - Australia

Environmentally responsible

Access to materials in other libraries

Sufficient funding to maintain free core services

Services clearly communicated to users

Adequate opening hours

Flexible loan system

Timely targeted training; effective library skills training

User friendly accurate catalogue

Facilities and equipment conducive to learning

Access to competent friendly proactive staff

Timely responsive service

Comprehensive Available relevant resources

Inspiring Environment supporting diverse needs

Easy, reliable access to, and delivery of library services

Extensive electronic resources

Easy Access to materials where \& when I need them
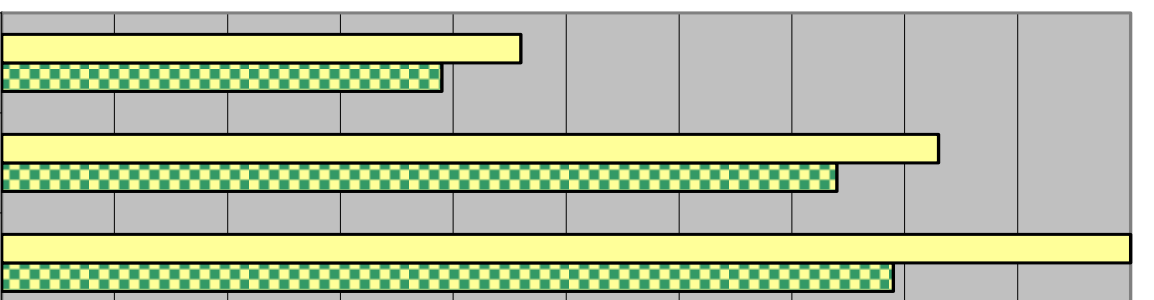

\section{8}
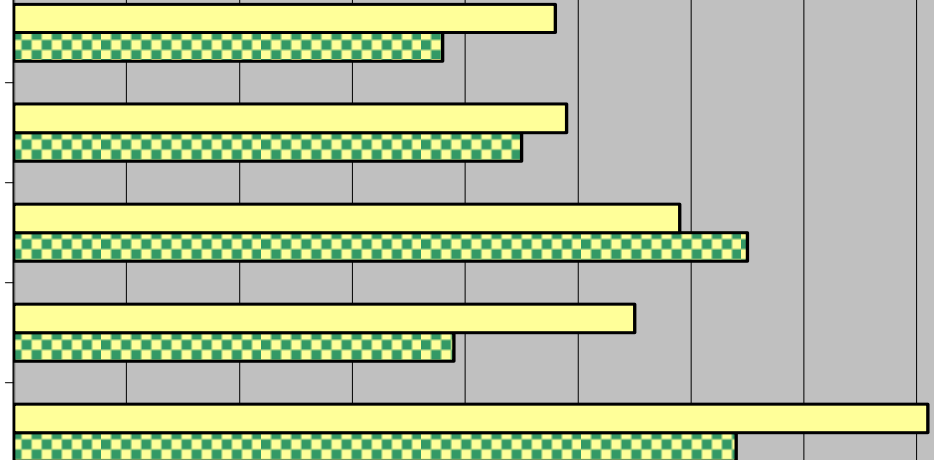

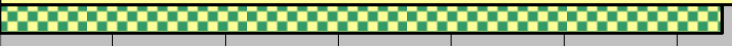
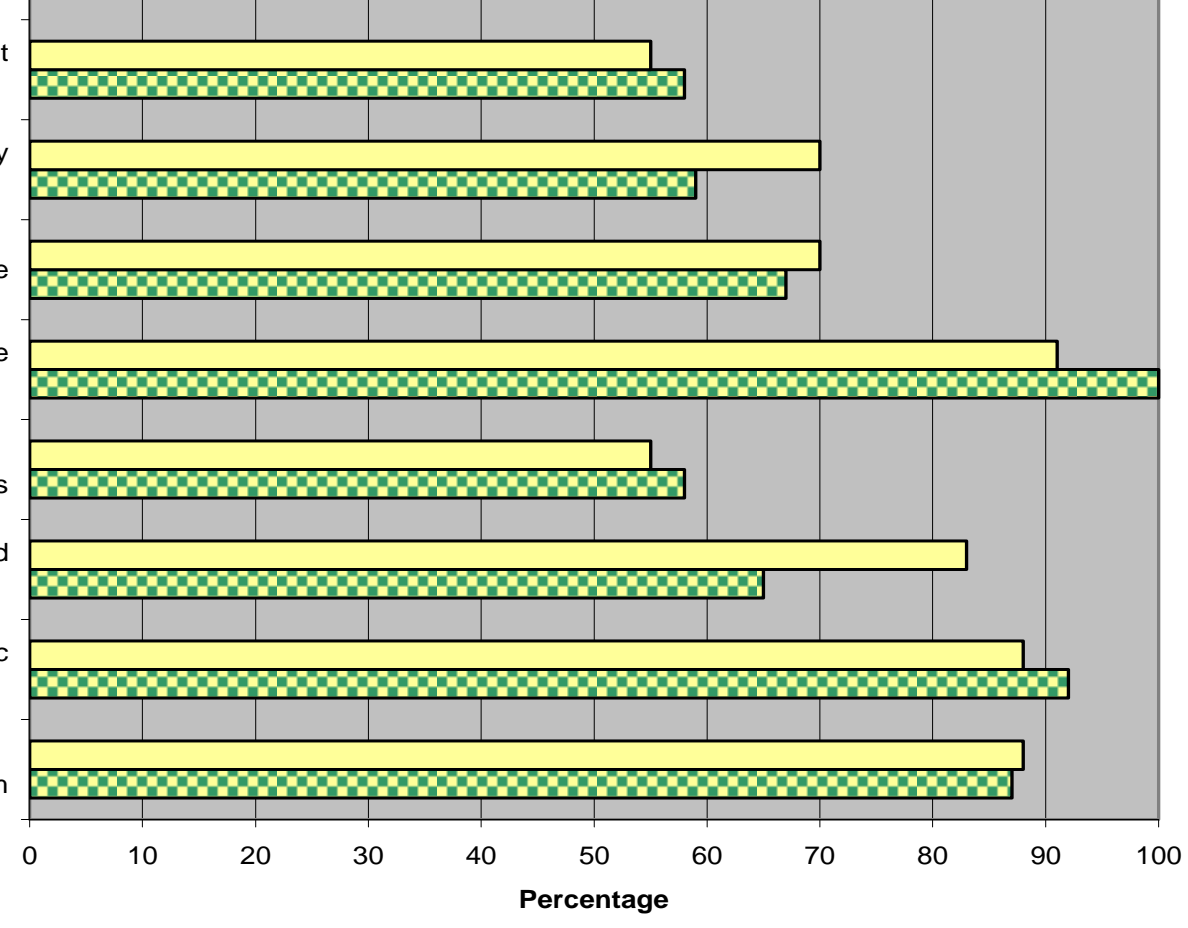

๑Australian Students

$\square$ Australian Academics 
Comparison of University Library Value Factors - England

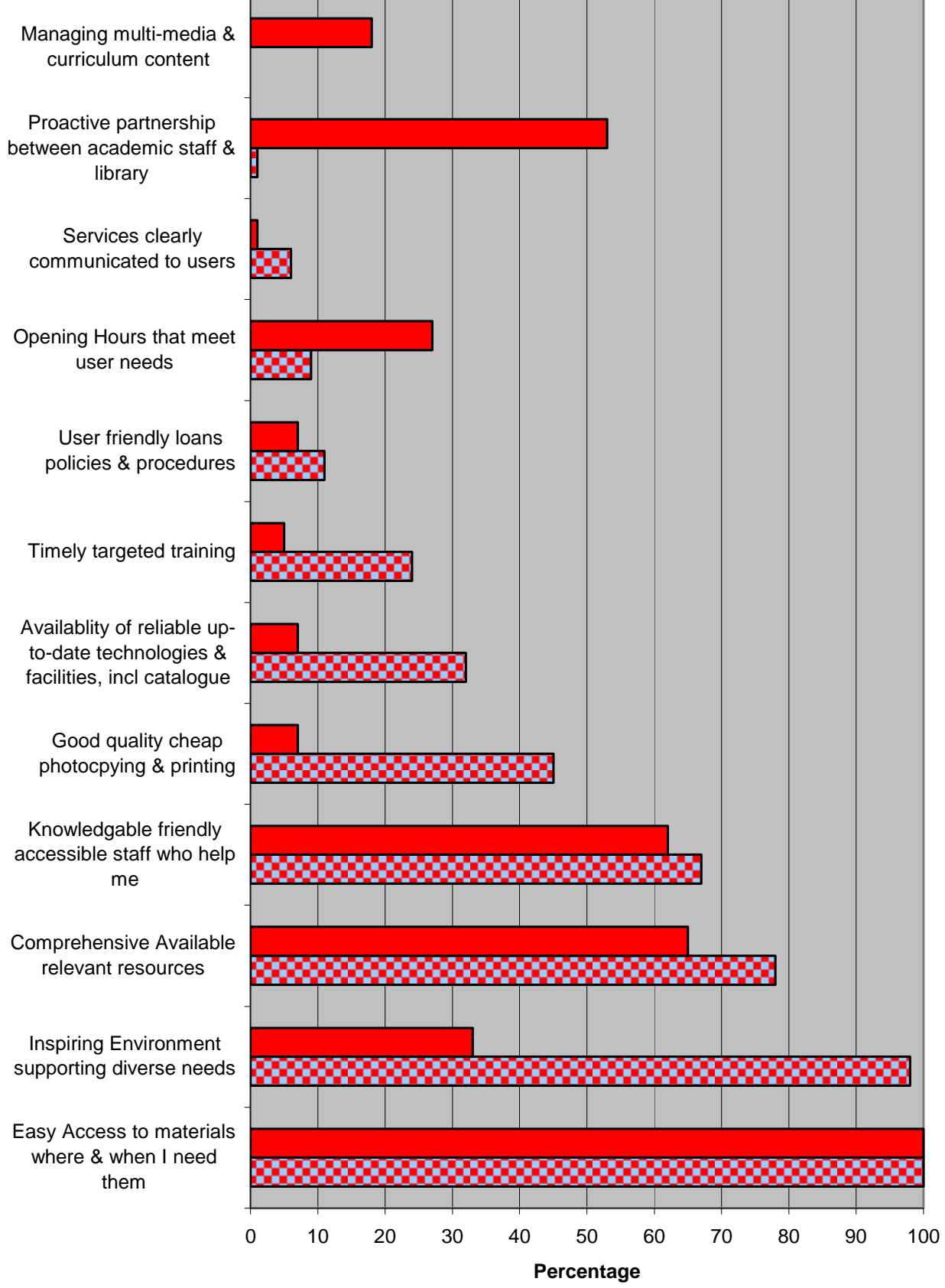

EEnglish Students

口English Academics 


\section{METHODOLOGY}

Both universities have multiple campuses, large student populations (over 25,000 ) and undertake research and teaching. Thus the resultant Hierarchies of Value for each library service offered the opportunity to compare the values for the respective customer groups. Over a period of years at Deakin University, a greater number of different customer segments were surveyed than is the case at Nottingham Trent University. However, to facilitate the comparison of values, only research data obtained from the same segments (on-campus undergraduate students; and academic staff) have been analysed here.

A brief description of the methodology is provided is warranted so as to be able understand the difference between this and the LibQUAL+ ${ }^{\mathrm{TM}}$ process.

Multiple facilitated Customer Value Discovery workshops are held for each unique customer segment. At each workshop, participants come from the same basic group (e.g. undergraduate students; postgraduate coursework students; postgraduate research students; off-campus students; international students; etc).

In the first part of the customer discovery workshops, the participants use a workbook sheet to identify and rate, in silence and individually, the irritants that they perceive about the existing services. This way, the issues are identified but there is no opportunity for "group think" and "one-upmanship" relating to problems experienced because there is no open discussion of the irritants in the workshop. These comments are gathered immediately for analysis after the workshops.

Unlike surveys with set questions, there are no preconceived ideas about what is important to customers. The participants are lead through a visioning exercise, where they are asked to imagine a time, three to five years on, when they have been successful in their endeavors at university, and they are asked to identify what services, provided by the library, which helped them achieve their success. Workbooks are used to capture individual thoughts and ideas, and then participants' top issues/values are captured into thematic sets using an affinity diagram (Six Sigma), which makes meaningful lists of similar ideas that resulted from the participants' visioning exercise. The facilitator then seeks a heading for each theme set from the customers present. The headings are then keyed into a voting response system and wireless keypads are used to capture the customers' responses (votes) by pairing each heading/Value with all the others through the forced pair comparison function of the software. This leads to the identification of the products/services in a hierarchy of importance i.e. Hierarchy of Value. The result is a defined set of values that inform decision making. The participants also vote on their perception of current performance of the identified Values, giving a gap analysis on importance and performance. 
The customers defined their own headings for the value and irritant factors at the workshop attended. There were multiple Customer Value Discovery workshops at least three workshops for each segment (undergraduate on-campus student and academic staff) at each university - so facilitated consolidation workshops were held at each university to bring the value and irritant factors together for each customer segment. Library staff who participated in the Customer Value Discovery workshops provided an overall heading for each group of Values and Irritants. As a result, some of the headings are repetitious where the thematic sets covered the same concept. However, the headings endeavoured to capture the essence of what the customers were saying, using the customers terms to describe the service, not how the library staff interpreted the comments. At all times at a consolidation workshop, if there was doubt as to the underlying concepts, the individual comments of the Customer Value Discovery participants was checked for clarification.

Throughout the workshop, library staff participate in the voting exercises, voting as they believe the customer will vote. In this way, a further gap analysis is developed between customer expectations and staff assumptions. This data is powerful for leading cultural change amongst staff. The aspect of the Customer Value Discovery process has been covered elsewhere. (McKnight, 2006)

Albrecht and Austin (1999) describe value modelling as "a special method for discovering the critical success factors for any venture by eliciting views of a selected group of experts in a structured feedback meeting." They go on to say that it is often used for customer research where the experts in the feedback meeting are the customers. Although extensively used in the commercial sector, customer value discovery, which is based on value modelling, has not been widely used in not-for-profit service organisations to identify customer perceptions of service excellence.

In both instances (Deakin University and Nottingham Trent University), the workshops for the two customer segments in the research study were held in the same period of time. Customer Values were ascertained from undergraduate oncampus students and academic staff at Deakin University in 1999. Customer Values were ascertained from undergraduate on-campus students and academic staff at Nottingham Trent University in 2005. A perceived weakness of the research methodology is the six year gap between the Australian and English Customer Value Discovery workshops. However, the interruption provides a window in which to compare if there are significant changes in the perceptions of academic library services over time. As the same methodology and a common facilitator were used in all cases, the outcomes (Hierarchies of Value and Irritation) are comparable.

A diagram of the Customer Value Discovery process follows. 


\section{Diagram 1: Customer Value Discovery Process $\odot$ Enzyme International (Aust.)}

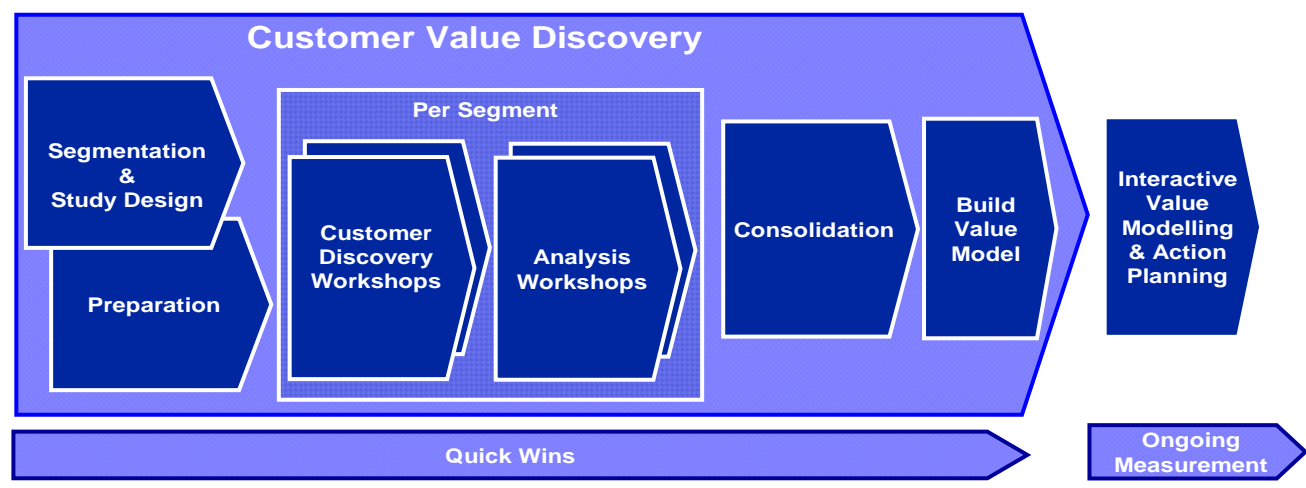

"Customer" refers to a target group

By way of background, in addition to Customer Value Discovery research, Nottingham Trent University library has undertaken LibQual+ ${ }^{\mathrm{TM}}$ benchmarking. Deakin University library has undertaken Rodski Customer Satisfaction surveys. During the research periods, the author was the library director at each institution.

\section{FINDINGS AND OBSERVATIONS}

The following tables have been constructed from the consolidated workshop data for the four customer segments: English and Australian on-campus students; and English and Australian academic staff. The tables use the LibQUAL+ ${ }^{\mathrm{TM}}$ headings and the customer Values and Irritations are noted where there is a correlation to the LibQUAL+ ${ }^{\mathrm{TM}}$ question. Note: Customer defined Irritants have been included in italics.

The value factors were largely consistent between Australia and England. However, there are different priorities attached to the various factors in the Hierarchies of Value. It is important to note the descriptions accorded the customer values when compared to the LibQUAL+ ${ }^{\mathrm{TM}}$ questions. The customer values use a terminology that reflects what the customers were describing in the various workshops and is devoid of library jargon. 


\subsection{Information Control}

This table maps the Values and irritants provided by the library customers as they relate the LibQUAL+ ${ }^{\mathrm{TM}}$ heading of 'Information Control'.

\section{Table 1. Comparison of Customer Identified Values with 'Information Control'}

\begin{tabular}{|c|c|c|c|c|}
\hline LibQUAL+ ${ }^{\text {TM }}$ & England Student & $\begin{array}{l}\text { Australian } \\
\text { Student }\end{array}$ & $\begin{array}{l}\text { England } \\
\text { Academic }\end{array}$ & $\begin{array}{l}\text { Australian } \\
\text { Academic }\end{array}$ \\
\hline $\begin{array}{l}\text { Making electronic } \\
\text { resources } \\
\text { accessible from } \\
\text { my home or office }\end{array}$ & $\begin{array}{l}\text { Easy access to } \\
\text { materials where } \\
\text { and when I need } \\
\text { them } \\
\text { Inadequacy of } \\
\text { collection and its } \\
\text { management }\end{array}$ & $\begin{array}{l}\text { Current, relevant, } \\
\text { comprehensive } \\
\text { collection } \\
\text { Extensive } \\
\text { electronic } \\
\text { resources } \\
\text { Easy, reliable } \\
\text { access to, and } \\
\text { delivery of, library } \\
\text { services } \\
\text { User friendly } \\
\text { accurate catalogue } \\
\text { Collection } \\
\text { Inadequacies } \\
\text { Difficulties with } \\
\text { technology and } \\
\text { electronic access }\end{array}$ & $\begin{array}{l}\text { Easy access to } \\
\text { materials where } \\
\text { and when I need } \\
\text { them } \\
\text { Managing multi- } \\
\text { media and } \\
\text { curriculum content } \\
\text { (VLE enabled) } \\
\text { Comprehensive } \\
\text { available relevant } \\
\text { resources } \\
\text { Inadequate } \\
\text { collection and its } \\
\text { management }\end{array}$ & $\begin{array}{l}\text { Current, relevant, } \\
\text { comprehensive } \\
\text { collection } \\
\text { Extensive } \\
\text { electronic } \\
\text { resources } \\
\text { Easy, reliable } \\
\text { access to, and } \\
\text { delivery of, library } \\
\text { services } \\
\text { User friendly } \\
\text { accurate catalogue } \\
\text { Collection } \\
\text { Inadequacies }\end{array}$ \\
\hline $\begin{array}{l}\text { A library web site } \\
\text { enabling me to } \\
\text { locate information } \\
\text { on my own }\end{array}$ & $\begin{array}{l}\text { Services clearly } \\
\text { communicated to } \\
\text { users } \\
\text { Inadequate } \\
\text { academic liaison \& } \\
\text { communication }\end{array}$ & $\begin{array}{l}\text { Easy, reliable } \\
\text { access to, and } \\
\text { delivery of, library } \\
\text { services } \\
\text { Services clearly } \\
\text { communicated } \\
\text { Difficulties with } \\
\text { technology and } \\
\text { electronic access } \\
\text { Poor } \\
\text { communication } \\
\text { and feedback }\end{array}$ & $\begin{array}{l}\text { Services clearly } \\
\text { communicated to } \\
\text { users }\end{array}$ & $\begin{array}{l}\text { Easy, reliable } \\
\text { access to, and } \\
\text { delivery of, library } \\
\text { services } \\
\text { Services clearly } \\
\text { communicated } \\
\text { Difficulties with } \\
\text { technology and } \\
\text { electronic access } \\
\text { Poor } \\
\text { communication and } \\
\text { feedback }\end{array}$ \\
\hline $\begin{array}{l}\text { The printed library } \\
\text { materials I need } \\
\text { for my work }\end{array}$ & $\begin{array}{l}\text { Comprehensive } \\
\text { available relevant } \\
\text { resources } \\
\text { Inadequacy of } \\
\text { collection and its } \\
\text { management }\end{array}$ & $\begin{array}{l}\text { Current, relevant, } \\
\text { comprehensive } \\
\text { collection } \\
\text { Materials not } \\
\text { where they are } \\
\text { supposed to be } \\
\text { Collection } \\
\text { Inadequacies }\end{array}$ & $\begin{array}{l}\text { Comprehensive } \\
\text { available relevant } \\
\text { resources } \\
\text { Inadequate } \\
\text { collection and its } \\
\text { management }\end{array}$ & $\begin{array}{l}\text { Current, relevant, } \\
\text { comprehensive } \\
\text { collection } \\
\text { Access to materials } \\
\text { in other libraries } \\
\text { Collection } \\
\text { Inadequacies }\end{array}$ \\
\hline The electronic & Easy access to & Current, relevant, & Easy access to & Current, relevant, \\
\hline
\end{tabular}




\begin{tabular}{|c|c|c|c|c|}
\hline $\begin{array}{l}\text { information } \\
\text { resources I need }\end{array}$ & $\begin{array}{l}\text { materials where } \\
\text { and when I need } \\
\text { them } \\
\text { Comprehensive } \\
\text { available relevant } \\
\text { resources } \\
\text { Inadequacy of } \\
\text { collection and its } \\
\text { management }\end{array}$ & $\begin{array}{l}\text { comprehensive } \\
\text { collection } \\
\text { Extensive } \\
\text { electronic } \\
\text { resources } \\
\text { Easy, reliable } \\
\text { access to, and } \\
\text { delivery of, library } \\
\text { services } \\
\text { Collection } \\
\text { Inadequacies }\end{array}$ & $\begin{array}{l}\text { materials where \& } \\
\text { when I need them } \\
\text { Comprehensive } \\
\text { available relevant } \\
\text { resources } \\
\text { Inadequate } \\
\text { collection and its } \\
\text { management }\end{array}$ & $\begin{array}{l}\text { comprehensive } \\
\text { collection } \\
\text { Extensive } \\
\text { electronic } \\
\text { resources } \\
\text { Easy, reliable } \\
\text { access to, and } \\
\text { delivery of, library } \\
\text { services } \\
\text { Managing multi- } \\
\text { media and } \\
\text { curriculum content } \\
\text { (VLE enabled) } \\
\text { Collection } \\
\text { Inadequacies }\end{array}$ \\
\hline $\begin{array}{l}\text { Modern } \\
\text { equipment that } \\
\text { lets me easily } \\
\text { access needed } \\
\text { information }\end{array}$ & $\begin{array}{l}\text { Good quality cheap } \\
\text { photocopying and } \\
\text { printing } \\
\text { Availability of } \\
\text { reliable up-to-date } \\
\text { technologies \& } \\
\text { facilities } \\
\text { Inadequate } \\
\text { expensive } \\
\text { photocopying \& } \\
\text { printing } \\
\text { Unreliable \& limited } \\
\text { IT and AV }\end{array}$ & $\begin{array}{l}\text { Easy, reliable } \\
\text { access to, and } \\
\text { delivery of, library } \\
\text { services } \\
\text { Facilities and } \\
\text { equipment } \\
\text { conducive to } \\
\text { learning } \\
\text { Difficulties with } \\
\text { technology and } \\
\text { electronic access } \\
\text { Difficulties with } \\
\text { printing and } \\
\text { photocopying }\end{array}$ & $\begin{array}{l}\text { Good quality cheap } \\
\text { photocopying and } \\
\text { printing } \\
\text { Availability of } \\
\text { reliable up-to-date } \\
\text { technologies \& } \\
\text { facilities } \\
\text { Inadequate } \\
\text { expensive } \\
\text { photocopying \& } \\
\text { printing } \\
\text { Unreliable and } \\
\text { limited IT and AV }\end{array}$ & $\begin{array}{l}\text { Easy, reliable } \\
\text { access to, and } \\
\text { delivery of, library } \\
\text { services } \\
\text { Difficulties with } \\
\text { technology and } \\
\text { electronic access } \\
\text { Difficulties with } \\
\text { printing and } \\
\text { photocopying }\end{array}$ \\
\hline $\begin{array}{l}\text { Easy-to-use } \\
\text { access tools that } \\
\text { allow me to find } \\
\text { things on my own }\end{array}$ & $\begin{array}{l}\text { Availability of } \\
\text { reliable up-to-date } \\
\text { technologies \& } \\
\text { facilities } \\
\text { Unreliable \& limited } \\
\text { IT and AV } \\
\text { Can't find materials } \\
\text { I need } \\
\text { Problems with } \\
\text { catalogue }\end{array}$ & $\begin{array}{l}\text { Easy, reliable } \\
\text { access to, and } \\
\text { delivery of, library } \\
\text { services } \\
\text { User friendly } \\
\text { accurate catalogue } \\
\text { Facilities and } \\
\text { equipment } \\
\text { conducive to } \\
\text { learning } \\
\text { Difficulties with } \\
\text { technology and } \\
\text { electronic access } \\
\text { Problems with the } \\
\text { catalogue }\end{array}$ & $\begin{array}{l}\text { Availability of } \\
\text { reliable up-to-date } \\
\text { technologies \& } \\
\text { facilities } \\
\text { Easy access to } \\
\text { materials where \& } \\
\text { when I need them } \\
\text { Unreliable and } \\
\text { limited IT and AV } \\
\text { Can't find materials } \\
\text { I need } \\
\text { Problems with } \\
\text { catalogue }\end{array}$ & $\begin{array}{l}\text { Easy, reliable } \\
\text { access to, and } \\
\text { delivery of, library } \\
\text { services } \\
\text { User friendly } \\
\text { accurate catalogue } \\
\text { Difficulties with } \\
\text { technology and } \\
\text { electronic access } \\
\text { Problems with the } \\
\text { catalogue }\end{array}$ \\
\hline $\begin{array}{l}\text { Making } \\
\text { information easily } \\
\text { accessible for } \\
\text { independent use }\end{array}$ & $\begin{array}{l}\text { Easy access to } \\
\text { materials where } \\
\text { and when I need } \\
\text { them } \\
\text { User friendly loans } \\
\text { policies \& }\end{array}$ & $\begin{array}{l}\text { Current, relevant, } \\
\text { comprehensive } \\
\text { collection } \\
\text { Extensive } \\
\text { electronic } \\
\text { resources }\end{array}$ & $\begin{array}{l}\text { Easy access to } \\
\text { materials where } \\
\text { and when I need } \\
\text { them } \\
\text { User friendly loans } \\
\text { policies and }\end{array}$ & $\begin{array}{l}\text { Current, relevant, } \\
\text { comprehensive } \\
\text { collection } \\
\text { Extensive } \\
\text { electronic } \\
\text { resources }\end{array}$ \\
\hline
\end{tabular}




\begin{tabular}{|c|c|c|c|c|}
\hline & $\begin{array}{l}\text { procedures } \\
\text { Restrictive \& } \\
\text { difficult loans } \\
\text { policies and } \\
\text { practices } \\
\text { Inadequacy of } \\
\text { collection and its } \\
\text { management } \\
\text { Can't find materials } \\
\text { I need } \\
\text { Problems with } \\
\text { catalogue } \\
\text { Inadequate opening } \\
\text { hours (Library } \\
\text { space issue/Access } \\
\text { Issue) }\end{array}$ & $\begin{array}{l}\text { Access to } \\
\text { materials in other } \\
\text { libraries } \\
\text { Easy, reliable } \\
\text { access to, and } \\
\text { delivery of, library } \\
\text { services } \\
\text { User friendly } \\
\text { accurate catalogue } \\
\text { Flexible loan } \\
\text { system } \\
\text { Materials not } \\
\text { where they are } \\
\text { supposed to be } \\
\text { Collection } \\
\text { Inadequacies } \\
\text { Difficulties with } \\
\text { technology and } \\
\text { electronic access } \\
\text { Problems with the } \\
\text { catalogue } \\
\text { Unsatisfactory } \\
\text { loan rules }\end{array}$ & $\begin{array}{l}\text { procedures } \\
\text { Opening hours } \\
\text { which meet user } \\
\text { needs } \\
\text { Restrictive \& } \\
\text { difficult loans } \\
\text { policies \& practices } \\
\text { Inadequate } \\
\text { collection and its } \\
\text { management } \\
\text { Inadequate opening } \\
\text { hours } \\
\text { Can't find materials } \\
\text { I need } \\
\text { Problems with } \\
\text { catalogue }\end{array}$ & $\begin{array}{l}\text { Easy, reliable } \\
\text { access to, and } \\
\text { delivery of, library } \\
\text { services } \\
\text { Flexible loan } \\
\text { system } \\
\text { Materials not } \\
\text { where they are } \\
\text { supposed to be } \\
\text { Difficulties with } \\
\text { technology and } \\
\text { electronic access } \\
\text { Collection } \\
\text { Inadequacies } \\
\text { Problems with the } \\
\text { catalogue } \\
\text { Unsatisfactory loan } \\
\text { rules }\end{array}$ \\
\hline $\begin{array}{l}\text { Print and/or } \\
\text { electronic journal } \\
\text { collections I } \\
\text { require for my } \\
\text { work }\end{array}$ & $\begin{array}{l}\text { Comprehensive } \\
\text { available relevant } \\
\text { resources } \\
\text { Inadequacy of } \\
\text { collection and its } \\
\text { management }\end{array}$ & $\begin{array}{l}\text { Current, relevant, } \\
\text { comprehensive } \\
\text { collection } \\
\text { Extensive } \\
\text { electronic } \\
\text { resources } \\
\text { Easy, reliable } \\
\text { access to, and } \\
\text { delivery of, library } \\
\text { services } \\
\text { Collection } \\
\text { Inadequacies }\end{array}$ & 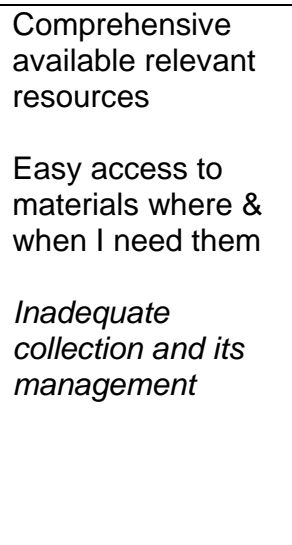 & $\begin{array}{l}\text { Current, relevant, } \\
\text { comprehensive } \\
\text { collection } \\
\text { Extensive } \\
\text { electronic } \\
\text { resources } \\
\text { Easy, reliable } \\
\text { access to, and } \\
\text { delivery of, library } \\
\text { services }\end{array}$ \\
\hline
\end{tabular}

Library information resources, encompassing any resource (books, journals, multi-media resources) regardless of format, are the highest value factor identified by both English and Australian students and English academic staff. Australian academics rated library information resources as their $2^{\text {nd }}$ highest value in 1999. These concepts are covered in four LibQUAL+ ${ }^{\mathrm{TM}}$ questions: 'Print and/or electronic journal collections I require for my work'; 'Printed library materials I need for my work'; 'The electronic information resources I need'; and 'Making electronic resources accessible from my home or office'. The customers, when asked, are not differentiating between monographs and journals, and not especially between print and electronic. 
The two English customer segments identified 'Easy access to materials where and when I need them' as the highest Value and 'Comprehensive available relevant resources' as $3^{\text {rd }}$ on the Hierarchy of Value. In Australia, the highest value factor was 'Comprehensive available relevant resources' with 'Ease of Access' $3^{\text {rd }}$ for the student cohort. The Australian customer cohorts explicitly identified 'Extensive electronic resources' and rated it very highly $\left(2^{\text {nd }}\right.$ for students; equal $3^{\text {rd }}$ for academic staff) whereas both English cohorts did not differentiate between electronic or print; they just wanted 'easy access', which implied, according to the individuals' comments, $24 \times 7$ access regardless of format.

The Australian students and staff rated highly the ability to gain access to resources in other libraries: both rating it $5^{\text {th }}$. The English cohorts did not mention this service.

The English academics identified 'managing multi-media \& curriculum content' as a value, albeit $7^{\text {th }}$ on the Hierarchy of Value. Curriculum resources, per se, were not mentioned by the other customer segments.

The concept of access also encompasses 'Services clearly communicated to users' because if customers do not know a service is available, then it does not exist. This Value was rated lowly by all customers: English students $-10^{\text {th }}$; English academics $-12^{\text {th }}$; Australian students $-16^{\text {th }}$; and Australian academics $15^{\text {th }}$. However, to have been included on the Hierarchy of Value means that it is an important service. Although listed in the table above with the LibQUAL+TM web site question, no values were identified by customers that related specifically to 'A library web site enabling me to locate information on my own'.

The other LibQUAL+ ${ }^{\mathrm{TM}}$ areas are covered: 'Modern equipment that lets me easily access needed information'; 'Easy-to-use access tools that allow me to find things on my own'; and 'Making information easily accessible for independent use'. However, the customers identified more specific values associated with modern equipment, specifically mentioning photocopying and audio/video equipment (English students rating this $5^{\text {th }}$; Australian students $-11^{\text {th }}$; English academics - equal $8^{\text {th }}$ and Australian academics - equal $11^{\text {th }}$ ). The customers also introduced the concepts of price and reliability as being of significance. The ease of use and accuracy of the catalogue were also highlighted by customers on both continents (English students $-6^{\text {th }}$; Australian students $-9^{\text {th }}$; English academics - equal $8^{\text {th }}$; and Australian academics $\left.-7^{\text {th }}\right)$.

Academics and students, regardless of country, identified 'User friendly loans policies \& procedures' or 'Flexible loan system' as a Value associated with access to the information resources they need (English students $-8^{\text {th }} ;$ Australian students $-7^{\text {th }}$; English academics - equal $8^{\text {th }}$; and Australian academics $-10^{\text {th }}$ ). This concept was not explicitly covered in the LibQUAL+ ${ }^{\mathrm{TM}}$ instrument. 


\subsection{Affect of Service}

This table maps the Values and irritants provided by the library customers as they relate the LibQUAL+ ${ }^{\mathrm{TM}}$ heading of 'Affect of Service'.

\section{Table 2. Comparison of Customer Identified Values with 'Affect of Service'}

\begin{tabular}{|c|c|c|c|c|}
\hline LibQUAL+TM & English Student & $\begin{array}{l}\text { Australian } \\
\text { Student }\end{array}$ & English Academic & $\begin{array}{l}\text { Australian } \\
\text { Academic }\end{array}$ \\
\hline $\begin{array}{l}\text { Library Staff who } \\
\text { install confidence } \\
\text { in Users }\end{array}$ & $\begin{array}{l}\text { Knowledgeable } \\
\text { friendly accessible } \\
\text { staff who help me } \\
\text { Unhelpful } \\
\text { uninterested staff }\end{array}$ & $\begin{array}{l}\text { Access to } \\
\text { competent, } \\
\text { friendly, proactive } \\
\text { staff }\end{array}$ & $\begin{array}{l}\text { Knowledgeable } \\
\text { friendly accessible } \\
\text { staff who help me } \\
\text { Unhelpful } \\
\text { uninterested staff }\end{array}$ & $\begin{array}{l}\text { Access to } \\
\text { competent, } \\
\text { friendly, proactive } \\
\text { staff }\end{array}$ \\
\hline $\begin{array}{l}\text { Giving users } \\
\text { individual attention }\end{array}$ & $\begin{array}{l}\text { Knowledgeable } \\
\text { friendly accessible } \\
\text { staff who help me } \\
\text { Unhelpful } \\
\text { uninterested staff } \\
\text { Queuing for service }\end{array}$ & $\begin{array}{l}\text { Timely responsive } \\
\text { service } \\
\text { Access to } \\
\text { competent, } \\
\text { friendly, proactive } \\
\text { staff } \\
\text { Service delays } \\
\text { Poor staff service }\end{array}$ & $\begin{array}{l}\text { Knowledgeable } \\
\text { friendly accessible } \\
\text { staff who help me } \\
\text { Unhelpful } \\
\text { uninterested staff } \\
\text { Queuing for service }\end{array}$ & $\begin{array}{l}\text { Timely responsive } \\
\text { service } \\
\text { Access to } \\
\text { competent, } \\
\text { friendly, proactive } \\
\text { staff } \\
\text { Service delays } \\
\text { Poor staff service }\end{array}$ \\
\hline $\begin{array}{l}\text { Library staff who } \\
\text { are consistently } \\
\text { courteous }\end{array}$ & $\begin{array}{l}\text { Knowledgeable } \\
\text { friendly accessible } \\
\text { staff who help me } \\
\text { Unhelpful } \\
\text { uninterested staff }\end{array}$ & $\begin{array}{l}\text { Access to } \\
\text { competent, } \\
\text { friendly, proactive } \\
\text { staff } \\
\text { Poor staff service }\end{array}$ & $\begin{array}{l}\text { Knowledgeable } \\
\text { friendly accessible } \\
\text { staff who help me } \\
\text { Unhelpful } \\
\text { uninterested staff }\end{array}$ & $\begin{array}{l}\text { Access to } \\
\text { competent, } \\
\text { friendly, proactive } \\
\text { staff } \\
\text { Poor staff service }\end{array}$ \\
\hline $\begin{array}{l}\text { Readiness to } \\
\text { respond to users' } \\
\text { enquiries }\end{array}$ & $\begin{array}{l}\text { Knowledgeable } \\
\text { friendly accessible } \\
\text { staff who help me } \\
\text { Unhelpful } \\
\text { uninterested staff }\end{array}$ & $\begin{array}{l}\text { Timely responsive } \\
\text { service } \\
\text { Access to } \\
\text { competent, } \\
\text { friendly, proactive } \\
\text { staff } \\
\text { Service delays } \\
\text { Poor } \\
\text { communication } \\
\text { and feedback } \\
\text { Poor staff service }\end{array}$ & $\begin{array}{l}\text { Knowledgeable } \\
\text { friendly accessible } \\
\text { staff who help me } \\
\text { Unhelpful } \\
\text { uninterested staff }\end{array}$ & $\begin{array}{l}\text { Access to } \\
\text { competent, } \\
\text { friendly, proactive } \\
\text { staff } \\
\text { Timely responsive } \\
\text { service } \\
\text { Service delays } \\
\text { Poor } \\
\text { communication } \\
\text { and feedback } \\
\text { Poor staff service }\end{array}$ \\
\hline $\begin{array}{l}\text { Library staff who } \\
\text { have the } \\
\text { knowledge to } \\
\text { answer user } \\
\text { questions }\end{array}$ & $\begin{array}{l}\text { Knowledgeable } \\
\text { friendly accessible } \\
\text { staff who help me } \\
\text { Unhelpful } \\
\text { uninterested staff }\end{array}$ & $\begin{array}{l}\text { Access to } \\
\text { competent, } \\
\text { friendly, proactive } \\
\text { staff } \\
\text { Poor staff service }\end{array}$ & $\begin{array}{l}\text { Knowledgeable } \\
\text { friendly accessible } \\
\text { staff who help me } \\
\text { Unhelpful } \\
\text { uninterested staff }\end{array}$ & $\begin{array}{l}\text { Access to } \\
\text { competent, } \\
\text { friendly, proactive } \\
\text { staff } \\
\text { Poor staff service }\end{array}$ \\
\hline $\begin{array}{l}\text { Library staff who } \\
\text { deal with users in a } \\
\text { caring fashion }\end{array}$ & $\begin{array}{l}\text { Knowledgeable } \\
\text { friendly accessible } \\
\text { staff who help me } \\
\text { Services clearly }\end{array}$ & $\begin{array}{l}\text { Access to } \\
\text { competent, } \\
\text { friendly, proactive } \\
\text { staff }\end{array}$ & $\begin{array}{l}\text { Knowledgeable } \\
\text { friendly accessible } \\
\text { staff who help me } \\
\text { Services clearly }\end{array}$ & $\begin{array}{l}\text { Access to } \\
\text { competent, } \\
\text { friendly, proactive } \\
\text { staff }\end{array}$ \\
\hline
\end{tabular}




\begin{tabular}{|c|c|c|c|c|}
\hline & $\begin{array}{l}\text { communicated to } \\
\text { users } \\
\text { Unhelpful } \\
\text { uninterested staff } \\
\text { Poor } \\
\text { communication and } \\
\text { feedback }\end{array}$ & $\begin{array}{l}\text { Timely responsive } \\
\text { service } \\
\text { Services clearly } \\
\text { communicated } \\
\text { Service delays } \\
\text { Poor } \\
\text { communication } \\
\text { and feedback } \\
\text { Poor staff service }\end{array}$ & $\begin{array}{l}\text { communicated to } \\
\text { users } \\
\text { Unhelpful } \\
\text { uninterested staff } \\
\text { Poor } \\
\text { communication and } \\
\text { feedback }\end{array}$ & $\begin{array}{l}\text { Timely responsive } \\
\text { service } \\
\text { Services clearly } \\
\text { communicated } \\
\text { Service delays } \\
\text { Poor } \\
\text { communication } \\
\text { and feedback } \\
\text { Poor staff service }\end{array}$ \\
\hline $\begin{array}{l}\text { Library staff who } \\
\text { understand the } \\
\text { needs of their } \\
\text { users }\end{array}$ & $\begin{array}{l}\text { Knowledgeable } \\
\text { friendly accessible } \\
\text { staff who help me } \\
\text { Proactive } \\
\text { partnerships } \\
\text { between academic } \\
\text { staff and Library } \\
\text { Unhelpful } \\
\text { uninterested staff } \\
\text { Inadequate } \\
\text { academic liaison \& } \\
\text { communication }\end{array}$ & $\begin{array}{l}\text { Timely responsive } \\
\text { service } \\
\text { Access to } \\
\text { competent, } \\
\text { friendly, proactive } \\
\text { staff } \\
\text { Poor staff service }\end{array}$ & $\begin{array}{l}\text { Knowledgeable } \\
\text { friendly accessible } \\
\text { staff who help me } \\
\text { Proactive } \\
\text { partnerships } \\
\text { between academic } \\
\text { staff and Library } \\
\text { Unhelpful } \\
\text { uninterested staff }\end{array}$ & $\begin{array}{l}\text { Access to } \\
\text { competent, } \\
\text { friendly, proactive } \\
\text { staff } \\
\text { Timely responsive } \\
\text { service } \\
\text { Poor staff service }\end{array}$ \\
\hline $\begin{array}{l}\text { Willingness to help } \\
\text { users }\end{array}$ & $\begin{array}{l}\text { Knowledgeable } \\
\text { friendly accessible } \\
\text { staff who help me } \\
\text { Unhelpful } \\
\text { uninterested staff }\end{array}$ & $\begin{array}{l}\text { Access to } \\
\text { competent, } \\
\text { friendly, proactive } \\
\text { staff } \\
\text { Timely responsive } \\
\text { service } \\
\text { Service delays } \\
\text { Poor staff service }\end{array}$ & $\begin{array}{l}\text { Knowledgeable } \\
\text { friendly accessible } \\
\text { staff who help me } \\
\text { Unhelpful } \\
\text { uninterested staff }\end{array}$ & $\begin{array}{l}\text { Access to } \\
\text { competent, } \\
\text { friendly, proactive } \\
\text { staff } \\
\text { Timely responsive } \\
\text { service } \\
\text { Service delays } \\
\text { Poor staff service }\end{array}$ \\
\hline $\begin{array}{l}\text { Dependability in } \\
\text { handling users' } \\
\text { service problems }\end{array}$ & $\begin{array}{l}\text { Knowledgeable } \\
\text { friendly accessible } \\
\text { staff who help me } \\
\text { Unhelpful } \\
\text { uninterested staff }\end{array}$ & $\begin{array}{l}\text { Timely responsive } \\
\text { service } \\
\text { Access to } \\
\text { competent, } \\
\text { friendly, proactive } \\
\text { staff } \\
\text { Service delays } \\
\text { Poor } \\
\text { communication } \\
\text { and feedback } \\
\text { Poor staff service }\end{array}$ & $\begin{array}{l}\text { Knowledgeable } \\
\text { friendly accessible } \\
\text { staff who help me } \\
\text { Unhelpful } \\
\text { uninterested staff }\end{array}$ & $\begin{array}{l}\text { Timely responsive } \\
\text { service } \\
\text { Access to } \\
\text { competent, } \\
\text { friendly, proactive } \\
\text { staff } \\
\text { Service delays } \\
\text { Poor } \\
\text { communication } \\
\text { and feedback } \\
\text { Poor staff service }\end{array}$ \\
\hline
\end{tabular}

The nine 'Affect of Service' questions relating to library staff in the LibQUAL+ TM instrument are far more detailed about behavioural characteristics than how library customers describe, in their own terms, the library staff they wish to encounter. Library customers want knowledgable, competent staff; 'friendly' is a positive behavioural characteristic identified; and 'accessible' and 'timely' 
introduce the notion of availability. The concept of 'proactivity' is also highlighted, both by the word being used in the Value descriptions and also implied in the Value description '... who help me'.

On the Hierarchy of Value, all cohorts rated staff highly, although the English related it higher than their Australian counterparts: English students $-4^{\text {th }}$ English academics $-3^{\text {rd }}$; Australian students $-10^{\text {th }}$; and Australian academics - equal $8^{\text {th }}$.

The English academics and undergraduate students identified the Value of a 'Proactive partnerships between academic staff and Library'. The individual comments from students under this heading were primarily related to reading list resources being available if such a relationship existed.

\subsection{Library as Place}

This table maps the Values and irritants provided by the library customers as they relate the LibQUAL+ ${ }^{\mathrm{TM}}$ heading of 'Library as Place'.

Table 3. Comparison of Customer Identified Values with 'Library as Place'

\begin{tabular}{|c|c|c|c|c|}
\hline LibQUAL+ $^{\text {TM }}$ & England Student & $\begin{array}{l}\text { Australian } \\
\text { Student }\end{array}$ & $\begin{array}{l}\text { England } \\
\text { Academic }\end{array}$ & $\begin{array}{l}\text { Australian } \\
\text { Academic }\end{array}$ \\
\hline $\begin{array}{l}\text { Library space that } \\
\text { inspires study and } \\
\text { learning }\end{array}$ & $\begin{array}{l}\text { Inspiring } \\
\text { environment which } \\
\text { supports diverse } \\
\text { needs } \\
\text { Noisy \& } \\
\text { inappropriate study } \\
\text { environment }\end{array}$ & $\begin{array}{l}\text { Facilities and } \\
\text { equipment } \\
\text { conducive to } \\
\text { learning } \\
\text { Poor physical } \\
\text { environment }\end{array}$ & $\begin{array}{l}\text { Inspiring } \\
\text { environment which } \\
\text { supports diverse } \\
\text { needs } \\
\text { Noisy \& } \\
\text { inappropriate study } \\
\text { environment }\end{array}$ & $\begin{array}{l}\text { Facilities and } \\
\text { equipment } \\
\text { conducive to } \\
\text { learning } \\
\text { Poor physical } \\
\text { environment }\end{array}$ \\
\hline $\begin{array}{l}\text { Quiet space for } \\
\text { individual work }\end{array}$ & $\begin{array}{l}\text { Inspiring } \\
\text { environment which } \\
\text { supports diverse } \\
\text { needs } \\
\text { Noisy \& } \\
\text { inappropriate study } \\
\text { environment }\end{array}$ & $\begin{array}{l}\text { Facilities and } \\
\text { equipment } \\
\text { conducive to } \\
\text { learning }\end{array}$ & $\begin{array}{l}\text { Inspiring } \\
\text { environment which } \\
\text { supports diverse } \\
\text { needs } \\
\text { Noisy \& } \\
\text { inappropriate study } \\
\text { environment }\end{array}$ & $\begin{array}{l}\text { Facilities and } \\
\text { equipment } \\
\text { conducive to } \\
\text { learning }\end{array}$ \\
\hline $\begin{array}{l}\text { A comfortable and } \\
\text { inviting location }\end{array}$ & $\begin{array}{l}\text { Inspiring } \\
\text { environment which } \\
\text { supports diverse } \\
\text { needs } \\
\text { Noisy \& } \\
\text { inappropriate study } \\
\text { environment }\end{array}$ & $\begin{array}{l}\text { Facilities and } \\
\text { equipment } \\
\text { conducive to } \\
\text { learning } \\
\text { Poor physical } \\
\text { environment }\end{array}$ & $\begin{array}{l}\text { Inspiring } \\
\text { environment which } \\
\text { supports diverse } \\
\text { needs } \\
\text { Noisy \& } \\
\text { inappropriate study } \\
\text { environment }\end{array}$ & $\begin{array}{l}\text { Facilities and } \\
\text { equipment } \\
\text { conducive to } \\
\text { learning } \\
\text { Poor physical } \\
\text { environment }\end{array}$ \\
\hline $\begin{array}{l}\text { A haven for study, } \\
\text { learning, or } \\
\text { research }\end{array}$ & $\begin{array}{l}\text { Inspiring } \\
\text { environment which } \\
\text { supports diverse } \\
\text { needs } \\
\text { Opening hours } \\
\text { which meet user } \\
\text { needs }\end{array}$ & $\begin{array}{l}\text { Facilities and } \\
\text { equipment } \\
\text { conducive to } \\
\text { learning } \\
\text { Adequate opening } \\
\text { hours }\end{array}$ & $\begin{array}{l}\text { Inspiring } \\
\text { environment which } \\
\text { supports diverse } \\
\text { needs } \\
\text { Opening hours } \\
\text { which meet user } \\
\text { needs }\end{array}$ & $\begin{array}{l}\text { Facilities and } \\
\text { equipment } \\
\text { conducive to } \\
\text { learning } \\
\text { Adequate opening } \\
\text { hours }\end{array}$ \\
\hline
\end{tabular}




\begin{tabular}{|c|c|c|c|c|}
\hline & $\begin{array}{l}\text { Noisy \& } \\
\text { inappropriate study } \\
\text { environment } \\
\text { Don't like card } \\
\text { access policies } \\
\text { Inadequate opening } \\
\text { hours }\end{array}$ & $\begin{array}{l}\text { Poor physical } \\
\text { environment } \\
\text { Limited hours of } \\
\text { access }\end{array}$ & $\begin{array}{l}\text { Noisy \& } \\
\text { inappropriate study } \\
\text { environment } \\
\text { Inadequate opening } \\
\text { hours }\end{array}$ & $\begin{array}{l}\text { Poor physical } \\
\text { environment } \\
\text { Limited hours of } \\
\text { access }\end{array}$ \\
\hline $\begin{array}{l}\text { Space for group } \\
\text { learning and group } \\
\text { study }\end{array}$ & $\begin{array}{l}\text { Inspiring } \\
\text { environment which } \\
\text { supports diverse } \\
\text { needs } \\
\text { Noisy \& } \\
\text { inappropriate study } \\
\text { environment }\end{array}$ & $\begin{array}{l}\text { Facilities and } \\
\text { equipment } \\
\text { conducive to } \\
\text { learning } \\
\text { Poor physical } \\
\text { environment }\end{array}$ & $\begin{array}{l}\text { Inspiring } \\
\text { environment which } \\
\text { supports diverse } \\
\text { needs } \\
\text { Noisy \& } \\
\text { inappropriate study } \\
\text { environment }\end{array}$ & $\begin{array}{l}\text { Facilities and } \\
\text { equipment } \\
\text { conducive to } \\
\text { learning } \\
\text { Poor physical } \\
\text { environment }\end{array}$ \\
\hline
\end{tabular}

The five LibQUAL+ ${ }^{\mathrm{TM}}$ questions in 'Library as Place' are encapsulated into one 'catch-all' descriptions by customers. An 'Inspiring environment which supports diverse needs' and 'Facilities and equipment conducive to learning' are broad descriptions that cover all the concepts in this section of LibQUAL+TM. English students rated the 'Library as Place' Value very highly $-2^{\text {nd }}$ in the Hierarchy of Value, while English academics rated it $5^{\text {th }}$. Australian students and Australian academics rated space equally at $11^{\text {th }}$. The concept of appropriate opening hours has been included in the 'Library as Place' section, in addition to considering it as an 'access' enabler, as it affects access to the physical space.

\subsection{Value Factors Not Specified in LibQUAL ${ }^{\mathrm{TM}}$}

In LibQUAL+ ${ }^{\mathrm{TM}}$, information literacy training is accorded a separate question regarding overall satisfaction (on a scale of 1-9) but does not go into the same depth as for the other three areas. However, the Hierarchies of Value and Irritation for all four customer segments specifically identify Information Literacy as a core value. 'Timely targeted training' was rated by the English student as $7^{\text {th }}$ and $11^{\text {th }}$ by the English academic. 'Effective library skills training' was rated by the Australian student as $14^{\text {th }}$ and $11^{\text {th }}$ by the Australian academic.

The Hierarchies of Value for the two Australian cohorts raise two Values that were not identified in the English research: 'Sufficient funding to maintain free core services' and 'Environmentally responsible'. These will be addressed in the discussion that follows.

\section{DISCUSSION}

The following explore some insights that resulted from an analysis of the comparisons of Values and of the comparison of the Values against the LibQUAL+ ${ }^{\mathrm{TM}}$ instrument. 
It is not the purpose of this paper to discuss specific cultural differences (if any) that may affect customers' Values associated with academic library services in Australia and England. As indicated earlier, Hofstede groups the two cultures into a common broad band. Indeed, Calvert (2001, p.732) suggests that there may be a global set of customer expectations that can be used to measure academic library service quality, based on comparative research he did using LibQUAL+ ${ }^{\mathrm{TM}}$ surveys in New Zealand and China. This research supports the notion of a common set of customer values associated with academic library services.

Nor is it necessary to understand the precise nature of the services and resources provides by either library service as the Customer Value Discovery research methodology, which results in the Hierarchy of Value, is based on the customers' perception of excellence and utopia not necessarily what is available at the time. Therefore, both sets of data in the respective Hierarchy of Value are comparable as representative of what customers expect from academic library services.

\subsection{Evolution of Values}

The six year period between when the two sets of data were gathered allows for time dependent observations. It is clear, from the individuals' descriptions captured in the thematic sets and the headings used, that customer expectations, if not Values, changed over time. For instance, in 1999, customers specifically mentioned electronic resources as a separate value factor. In 2005, electronic resources were described by the workshop participants as part of a basic suite of information resources that enabled "easy access whenever and where ever I need them".

Again in 1999, the library online catalogue was singled out as a specific Value. By 2005, the catalogue had become one of a number of tools customers described that supported learners' access to information resources. By 2005, federated search services, using products such as Ex Libris' SFX and Metalib, play as significant a role as the traditional library catalogue. Regardless, Irritants were identified regarding the catalogue, emphasising the crucial role that it still plays in facilitating access to information.

The evolving nature of what is regarded as Value to the customer will continue to change over time. As what were once new services become mainstreamed, these become expected services and will not necessarily attract specific mention. However, new services will emerge. To stay relevant the LibQUAL+ ${ }^{T M}$ instrument will have to be revised as time goes on to make sure that its questions remain relevant to the library community from which it seeks feedback.

\subsection{Terminology}


One of the benefits of the Customer Value Discovery model is that it allows library customers to express themselves freely about what is important to them. Sometimes the words used are emotive or at least reflect the impact that services and resources have on students and academic staff. They describe their values, not what librarians think is important.

For instance, librarians tend to be concerned with format and type: books, eBooks, paper journals, eJournals, and multi-media audio visual resources. This may be because the different formats and type tend to be handled differently from ordering, receipt and to housing. The LibQUAL+ ${ }^{T M}$ instrument reflects these concerns. However, library customers think of information resources as a total package, disregarding the nuances between books, printed resources and digital resources. Students, in particular, are more likely to differentiate information resources as to whether the item is on a reading list or not, however, they want information 'stuff' regardless of format.

Performance-related methodologies that rely on structured pre-defined questionnaires risk the introduction of questions that can be biased towards library management perceptions of what is important to customers. It is important to give library customers the opportunity to state, in their own words, what is really important to them.

\subsection{Library Staff Qualities}

The areas explored by the LibQUAL+ ${ }^{\mathrm{TM}}$ instrument tend to be more behaviourally focussed. There are nine distinct attributes identified. Customers, on the other hand, do not see the minute elements of staff attributes. They see only the whole package of the personal interaction with a library staff member. Their Value is expressed in a single description in both the Australian and English Hierarchies. From reviewing the individual comments, it is apparent that library customers do not differentiate between professional librarians, para-professional or support staff. All staff are expected to be competent and friendly. Customers, in the Australian workshop, debated whether 'friendly' was a necessary characteristic; they agreed it was a value but that competent and knowledgable was more important.

\subsection{Access and Availability}

A significant number of the customer values relate to 'access': to information resources; to library staff; to technology and equipment; to an easy-to-use catalogue; and appropriate opening hours. These concepts were identified in a myriad of Values associated with all three of the LibQUAL+ ${ }^{\mathrm{TM}}$ main topics.

Further analysis of the individual comments from customers demonstrate that access can relate to: physical information resources being where the catalogue indicates its location; PCs and other equipment being provided in sufficient 
numbers to make 'easy' access possible; speedy access to staff on duty so that questions can be quickly answered; as well as $24 \times 7$ access to electronic resources. 'Easy access to materials ...' related to the availability of reading list material, whether it is in a short-loan collection, on the shelves, or in a digital reserve file, as well as $24 \times 7$ ejournal access and the like.

The LibQUAL+TM instrument specifically refers to the library web site. Customers did not single the web site out, but referred to a broad range of signing and guiding information, from the web site, printed brochures, shelf labels, signposting within the building and layout maps.

\subsection{Uniquely Identified Values}

Values identified by the customers, and not explicitly reflected in LibQUAL+TM, relate to opening hours and flexible loans policies. As previously mentioned, these were in relation to the issue of access: borrowing limits that are generous; and the physical library being open for extended periods to facilitate borrowing and access to IT facilities.

English customers also defined the relationship between library staff and academic staff as an explicit Value. This Value has been located with 'Library staff who understand the needs of their users' in the LibQUAL+ ${ }^{\mathrm{TM}}$ comparison, as it implies knowledge gained from a proactive liaison will be of benefit to the customers. One possible reason for this factor appearing as a separate Value in the English Hierarchy relates to the combined service of library and eLearning at the English university. Although, as already mentioned in the findings above, English students referred to the liaison that resulted in reading list material being available in the library.

'Managing multi-media and curriculum content' was identified for the first time in the English study in 2005. This is attributed to the experience of students and academic staff using content in virtual learning environments. From the descriptions of individual respondents, the capability to search and access learning content, as opposed to library content, is an emerging Value factor. The customers did not discriminate as to the type of information; they just wanted it to be as easy to find as other [library] information resources. In 1999, there is no mention of this type of development. Again, the organisational structure may have influenced the customers' perceptions of what might be possible at the English university.

In the Australian research, 'Sufficient funding to maintain free core services' was identified. The Value has an emphasis on 'free'. The Australian higher education sector at that time was being encouraged to become more business focussed and to acknowledge the costs of services. There was concern that funding may not be maintained and that charges for value-adding services may be levied. There was also recognition in the comments that a library requires sufficient 
funding if it is to innovate with new electronic resources and services. This is perhaps the only 'cultural value' of significant difference between Australia and England, recognising different government expectations with regard to higher education funding,

'Access to materials in other libraries' did not relate to the Australian multicampus environment. It referred to linkages with other libraries that facilitated access to other library information resources, such as inter-library loans. The English customers did not explicitly refer to this type of service. One reason suggested for this is the increasing availability of full-text journals online; there is less demand for inter-library loans.

Being 'Environmentally responsible' was the final unique Value identified by the Australian library customers. The consolidation workshop details concerns about 'the library acting responsibly at all times to minimise damage to the environment and to discourage waste'. Given that recycling is now becoming important in English universities, this Value may appear if the research is undertaken in 2008.

\subsection{Academic and Student Comparisons}

For the English students, the top four Values were 'Easy access to materials where and when I need them'; 'Inspiring environment supporting diverse needs', 'Comprehensive available relevant resources and 'Knowledgeable friendly accessible staff'). The English academics top four were the same except for substituting 'Proactive partnership between academic staff and library' with the space value. In Australia, the students rated the Values relating to the information resources with similar importance, but valued the staff slightly less than in England. Australian academics rated the Value 'Sufficient funding to maintain free core services' the highest. All the collection related Values followed immediately after that. The Australian academic rated the Value of library staffing higher than the Australian students, but still not as important as their English counterparts.

\subsection{The Value of Irritants}

The Customer Value Discovery methodology is based on a simple hierarchy of value. At one end the customer is angry. At the other end of the spectrum, the customer is delighted by the unanticipated services/products that are available to them. In between, there are gradations of irritation and satisfaction based on the perceptions and needs of the customer. The hierarchy includes: Angry, Irritated, Frustrated, Basic, Expected, Desired, and Unanticipated.

Unlike a straight satisfaction rating, Value Modelling takes into account how seriously Irritants impact upon a customer and how frequently these occur. This is balanced against the corresponding Value factor (if there is one) of how important it is to deliver value, and how the customers' current perception of 
service is rated. The model does not give a total level of satisfaction, but shows that in all complex services/products sometimes customers are annoyed and sometimes delighted, and it can happen in the same interaction. The total value is derived by taking away the irritation factor from the delighted (value) factors and deriving a total score of 'value'. Value runs from the Origin to +100 and Irritation Index runs from the Origin down to -100 . The model can be re-run at any stage to assess the impact of removing irritation and adding value. As the model takes into account all the Values and Irritants, the software can be re-run to demonstrate the overall impact of all potential interventions. So, knowledge of the Irritants is necessary to understand how the customer perceives current performance, satisfaction and value.

Two types of Irritation were found in the comparative studies. The first was a description by the customers of the opposite of what a successful library service looked like. These were corollaries to the Value factors, citing lack of delivery of the core values. Examples of these are: Noisy \& inappropriate study environment; Inadequacy of collection and its management; Unhelpful uninterested staff. Interestingly, the Australian cohorts rated 'Access to competent, friendly, proactive staff' lower than their counterparts in England. However, they did not identify any Irritants associated with staff. This supports the notion that the Value of services that are considered 'basic' by the customer will be rated higher in important (value) if the perception is that the service is not up to standard, as indicated in Kano's model.

The second type of Irritant appears to be local to the university library being researched. Although these Irritants can be mapped to a LibQUAL+ ${ }^{\mathrm{TM}}$ heading, the details are more specific and local: noise in the library being mentioned in the English study but not in Australia; queuing for service was another issue in the English study. The benefit of these Irritants is that it enables library managers to target areas of annoyance to achieve quick wins for the customer.

\section{CONCLUSION}

Do library managers really know what library customers value? The answer is 'YES' only if we ask customers specifically what they value. The LibQUAL+ ${ }^{\mathrm{TM}}$ instrument is an effective tool identifying most of the Values identified by the Australian and English undergraduate on-campus students and academic staff. However, each methodology provided unique data. All the data is likely to be useful in guiding decision-making, even if LibQUAL+TM explores some areas in depth, the relevance of which may not be immediately apparent to the customers.

Is there a core set of academic library customer values? Yes. Appropriate Library Space; Competent Staff; Core Reading List Materials; Relevant Collection (books and journals); Access tools e.g. catalogue, online databases; Communication of services via Web Site, Signage and Guiding; Photocopiers and Printers; 
Appropriate Opening Hours; Appropriate Borrowing Policies; Information Literacy Skills Training.

Can library managers rely on the key areas identified in longstanding benchmarking instruments? Yes, as long as the instruments evolve with the changing expectations of library customers. Any revision of the instruments should take into account the perceptions of customer needs as well as improving data gathering for library managers.' Will the customer care?' ought to be a question asked before finalising any survey instrument.

Is there a difference between what Australian academic library customers value and those of their English counterparts? No, not really in this case. Both libraries served similar customer numbers and discipline mix at the time of the research and experienced the challenges of multi-campus sites. The majority of differences can probably be explained by the progress along Kano's basic services graph, where more of a service results in greater satisfaction, and less causing dissatisfaction (Kano, Seraku, Takahashi \& Tsuji, 1996).

Do values change over time? Yes, definitely. The problem, if it can be called that, of consistently delivering on 'value adding' services, is that these, over time, are no longer considered as 'wow' and become expected, basic services. So the bar is always being lifted on delivering value-adding and unanticipated service delivery delights. Values also change as a result of non-delivery of basic services. For instance, no customer said they valued physical spaces that are maintained at the right temperature and right noise levels. This was assumed as normal. However, the value of that expected service increases if the physical environment declines for whatever reason.

A major benefit of LibQUAL+ ${ }^{\mathrm{TM}}$ is its benchmarking capability, if this is important in your sector or region. It is cost effective to administer, with many library customers being able to complete the online survey. It also provides perceptions of satisfaction for the library service. However, the reports can be difficult to interpret (Bower \& Bradford, 2007; Roszkowski, Baky and Jones, 2005).

The Customer Value Discovery methodology involves far fewer respondents per customer segment (perhaps 80) to give a valid set of Hierarchies of Value and Irritation. The graphical representation of the hierarchies is easy to interpret and the irritation factors, which most often are the corollary of the value factor, provide information to managers for immediate action to reduce the irritation. It is also a facilitated exercise which raises the costs of the research exercise.

The major difference between the two methodologies is the active participation of library staff in the Customer Value Discovery process. Personal involvement and understanding makes the implementation of changes resulting from the Customer Value Discovery process much easier to implement because of the personal and emotional understanding that comes from listening to what the 
customers are saying. A drawback, however, is that the process precludes benchmarking with other library services. The results relate to the particular library service and it is not possible to measure performance against the values with other libraries, as the 'sum total of satisfaction' is the level of value derived minus the irritants encountered today, in that library.

Managers need both customer values, identified by the customers themselves, and satisfaction rates to make sure that there are no assumptions made about customer preferences. The major factor towards delivering customer satisfaction, though, is to do something constructive with the data gained through either or both methodologies.

Future research at Nottingham Trent University will be to compare the results of the LibQUAL+TM survey, which was conducted in 2007, with the results of the Customer Value Discovery research data obtained in 2005. 


\section{REFERENCES}

Albrecht, K. and Austin, A. (1999) Value Modelling: Executive Overview, Austin Thompson \& Associates Pty Ltd (now Enzyme International (Aust.), Sydney.

Bower, T. and Bradford, D. "How to get more from your quantitative LibQUAL+ ${ }^{\mathrm{TM}}$ dataset: making results practical", Performance Measurement and Metrics, Vol 8, No 2, pp.110-126.

Brophy, P. (2006) "Impact Measurement: Introduction and Issues", SCONUL Autumn Conference, British Library, London.

http://www.sconul.ac.uk/events/egm2006/presentations/Brophy.ppt

Calvert, Philip J. (2001), International Variations in Measuring Customer Expectations, Library Trends, Vol.49, No.4, pp.732-757.

Hofstede, G. (1983), "National cultures in four dimensions: a research-based theory of cultural differences amongst nations", International Studies of Management and Organizations, Vol XIII, No 2, pp.46-74.

Kano, N., Seraku, N., Takahashi, F. and Tsuji, S. (1996) "Attractive quality and must-be quality", in J.D. Hromi (Ed.) The best on quality,. Vol 7 of the Book Series of the International Academy for Quality, ASQC Quality Press Milwaukee.

McKnight S. (2006) Customers Value Research", in Management, marketing and promotion of library services based on statistics, analyses and evaluation. ed. Trine Kolderup Flaten. Munich: K.G. Saur, IFLA Publications 120/121, pp. 206216.

McKnight, S. and Berrington, M. (2008) "Improving Customer Satisfaction: Changes as a result of Customer Value Discovery", Evidence Based Library and Information Practice, http://ejournals.library.ualberta.ca/index.php/EBLIP March, pp.33-52.

Roszkowski, M., Baky, J. and Jones, D. (2005) "So which score on the LibQUAL ${ }^{T M}$ tells me if library users are satisfied?", Library \& Information Science Research, Vol 27 No 4, Autumn pp. 424-439.

Six Sigma. Affinity Diagram explanation.

http://www.isixsigma.com/offsite.asp?A=Fr\&Url=http://www.skymark.com/resourc es/tools/affinity diagram.asp

Warnaby, G. and Finney, J. (2005) "Creating customer value in the not-for-profit sector: A case study of the British Library", The International Journal of Nonprofit \& Voluntary Sector Marketing, August, pp. 183-195. 